THE ALABAMA CLA MS

American Politics and

Anglo-American Relations, 1865-1872 
Also by Adrian Cook

The Armies of the Streets: The New York City Draft Riots of 1863 


\section{THE ALABAMA CLAIMS}

American Politics and

Anglo-American Relations, I865-I872

\section{ADRIAN COOK}

Cornell University Press 
Copyright (C) 1975 by Cornell University

All rights reserved. Except for brief quotations in a review, this book, or parts thereof, must not be reproduced in any form without permission in writing from the publisher. For information address Cornell University Press, 124 Roberts Place, Ithaca, New York 14850.

First published 1975 by Cornell University Press.

Published in the United Kingdom by Cornell University Press Ltd., 2-4 Brook Street, London W1Y 1AA.

International Standard Book Number 0-8014-0893-8

Library of Congress Catalog Card Number 74-10408

Printed in the United States of America by Cayuga Press, Inc. 
To a signalman of the Great Western Railway 1902-1964 
